\title{
Strategies for building trust with farmers: the case of Bt maize in South Africa
}

Obidimma C Ezezika ${ }^{1,2,3^{*}}$, Robin Lennox ${ }^{1}$, Abdallah S Daar ${ }^{1,4,5}$

\begin{abstract}
Background: In 1999, South Africa became the first African country to approve commercial production of subsistence genetically modified (GM) maize. The introduction of GM crop technology is often met with skepticism by stakeholders including farmers. The involvement of the private sector in this process can further breed mistrust or misperceptions. To examine these issues more closely, the objective of this case study was to understand the role of trust in the public-private partnership (PPP) arrangement involved in the development of Bacillus thuringiensis (Bt) maize in South Africa.

Methods: We conducted semi-structured, face-to-face interviews to obtain stakeholders' understanding of trust in general as well as in the context of agricultural biotechnology (agbiotech) PPPs. A thematic analysis of the interview transcripts, documents, reports and research articles was conducted to generate insights into the challenges to, and practices for, building trust among the partners and with the public.

Results: The findings of this study are organized into four main lessons on trust building. First, as the end users of GM technology, farmers must be engaged from the start of the project through field demonstrations and educational activities. Second, an effective technology (i.e., the seed) is key to the success of an agbiotech PPP. Third, open communication and full disclosure between private sector companies and government regulatory bodies will build trust and facilitate the regulatory processes. Fourth, enforcing good agronomic practices, including appropriate management of the refuge areas, will serve the interests of both the farmers and the seed companies.

Conclusions: Trust has proven to be a critical factor determining the success of the Bt maize project in South Africa. Distrust of the private sector and of GM technology were cited as major barriers to building trust. The trustbuilding practices described in this case study have often served to overcome these barriers; however, erosion of trust was also present. The success of the project has been, and will continue to be, dependent upon the concerted effort of the farmers, government, and private sector players in the establishment and maintenance of trust.
\end{abstract}

\section{Background}

\section{History of Bt maize in South Africa}

One of the major challenges hindering the production of maize, a staple food in South Africa, is the damage to crops caused by maize stalk borers [1]. Studies have estimated that the annual loss in maize due to the stalk borer is about one million tonnes, which is valued at approximately US $\$ 2.7$ billion [2]. In response to the challenge posed by the stalk borer globally, scientists and

\footnotetext{
* Correspondence: obidimma.ezezika@srcglobal.org

'Sandra Rotman Centre, University Health Network and University of

Toronto, Toronto, Ontario, Canada

Full list of author information is available at the end of the article
}

private companies began developing Bacillus thuringiensis (Bt) maize, a genetically-modified (GM) crop that is resistant to stalk borer insect pests. Bt maize was first approved for commercial production in South Africa in 1998. South Africa was in fact the first African country to approve the commercial production of a GM subsistence crop [3,4]. As of 2011, the adoption of biotech crops in South Africa had reached 2.3 million hectares, $81 \%$ (1.873 million hectares) of which was biotech maize [5]. The increase in hectarage may be attributable to a yield advantage of $11.03 \%$ and $10.60 \%$ on irrigated farms and dry land, respectively, when using Bt maize as opposed to

\section{() Biomed Central}


conventional maize [4]. This impact is expected to be even greater where the stem borer infestation is higher.

The production of Bt maize, like that of other GM crops, was fuelled by commercial interests of private companies such that GM crops were used primarily for commercial farming [3]. Initial efforts at commercializing Bt maize was spearheaded by two private companies: Monsanto Company and Syngenta [2]. The genetically modified organisms (GMO) Act was passed in 1997, allowing active GM work in South Africa to commence. Prior to that, the South African Committee for Genetic Experimentation (SAGENE), an association of industry experts, developed guidelines that served as a watchdog and advisory body to scientists, industry and government on matters of agricultural biotechnology (agbiotech) [6].

Monsanto is the key player in the Bt maize industry in South Africa. Monsanto's Bt genes are found in the company's own hybrids and, at the same time, it has licensed the technologies to Pioneer Hibred and Pannar Seed companies, which have introgressed the genes into their own hybrids [4]. Monsanto's monopoly on Bt maize in South Africa ended in 2003, which is when Syngenta's Bt maize was approved by the Department of Agriculture [4]. Syngenta's Bt genes - introgressed with maize varieties to confer resistance to the maize stalk borer - have been commercialized in a joint venture with Seedco Seed Company. Dow Chemicals is another company that has tried its Bt genes in South Africa, in collaboration with Pioneer Hibred South Africa [4].

In addition to the private sector actors involved, two not-for-profit organizations were integral to the success of commercializing Bt maize in South Africa: the Agricultural Research Council (ARC) and AfricaBio. The ARC is the largest agricultural research organization in South Africa [7]. AfricaBio is a biotechnology stakeholders association whose mandate is to share knowledge, information, and awareness of biotechnology_including Bt maize-and its proper management [8]. AfricaBio has supported many promotional and community engagement initiatives, such as the on-site demonstrations of Bt maize (see Additional file 1 for the roles of the key collaborators/partners in the Bt maize partnership in South Africa).

The institutions (private companies, government institutions and others) engaged in Bt maize production in South Africa are not linked through a typical or formal publicprivate partnership (PPP) arrangement. Instead, this initiative was driven by "a system of collaboration" comprised of government actors, non-governmental organizations (NGOs), and private sector companies. This system of collaboration was built upon a shared objective to reduce the amount of maize crop yield lost due to the maize stem borer. While there was no formal PPP in place throughout the introduction of Bt maize in South Africa, the lessons on trust building and collaboration drawn from this case study are certainly generalizable to more formal agbiotech PPPs.

Trust among partners and with the public has been identified as an important element of successful PPPs [9]. Factors affecting the establishment, development, and maintenance of trust in PPPs can either ensure or compromise the success of agbiotech projects as a whole. Trust is especially critical in agbiotech PPPs, as the introduction of GM crops can often be contentious and hindered by public mistrust in private sector involvement. The involvement of the private sector in these PPPs can often breed skepticism, as the public sector often perceives the intentions of the private sector as suspect $[10,11]$. In particular, a fear exists within the public sector that multinational biotechnology companies may seek to take advantage of the resource-constrained nations in which they operate PPPs [12]. In some cases, this distrust is met by similar hesitations on the part of the private sector, which views the public sector as slow, inefficient, and resistant to new technologies [11]. These underlying issues form the basis of this case study, which seeks to investigate existing trust-building practices that may serve to overcome barriers to trust in agbiotech PPPs.

This study constitutes one in a series of eight case studies investigating the role of trust in agbiotech PPPs and the adoption of GM crops in sub-Saharan Africa. Trust is important in agbiotech PPPs as its presence enables partners to complete complex, long-term tasks and achieve intended results $[13,14]$.

The three specific goals of this series of case studies are to: 1$)$ describe trust-building practices in the development of agbiotech projects; 2) describe the challenges associated with trust building in PPPs; and 3) determine what makes these practices effective or ineffective. This particular study seeks to accomplish these goals by describing and analyzing the trust-building practices undertaken during the commercialization process of $\mathrm{Bt}$ maize in South Africa. By identifying barriers to trust and trust-enhancing practices, this study provides insight to potential funders, researchers, farmers and others about successful management of agbiotech PPPs.

\section{Methods}

A total of twelve individuals, drawn from both the public and private sector, were interviewed for this study. They included three small-scale and two large-scale maize farmers; representatives from the private sector companies Monsanto Company, Pioneer Hibred and Pannar; a representative from the Council for Scientific and Industrial Research (CSIR); and a representative from the Maize Trust in South Africa.

Interviewees were identified by making a list of key individuals associated with the project based on the stakeholders identified within the research protocol. This list 
was then populated further through snowball sampling. Potential interviewees were sent an invitation, which contained an explanation of the case study series, to participate in the interview. Those who consented to participate were informed that the interview would be recorded, transcribed and analyzed.

All the interviews took place in South Africa. They followed a semi-structured, face-to-face format and each lasted approximately one hour. The interview guide included questions on the interviewees' background, their understanding of the project, and their interpretation of the word trust. The interview explored perceptions of trust among the partners and with the public, apparent challenges to trust, and observed trust-building practices. Finally, interviewees were asked for their suggestions on how to improve agbiotech PPPs (see Additional file 2 for sample questions from the interview guide).

The interviews were transcribed verbatim. The analysis was performed by reading through the transcripts several times, identifying trends and organizing them into major themes. A literature review of academic articles and project documents were also used in the writing of the report. Research Ethics Board (REB) approval for this study was obtained prior to conducting the case study from the University Health Network, University of Toronto.

\section{Results and discussion}

\section{Interviewees' understanding of trust}

Interviewees were asked to define trust and identify its elements in the context of the Bt maize project in South Africa. The key elements of trust, as identified by the participants, were honesty and delivery of accurate information in a timely manner. One interviewee defined trust as "being honest, [and] sharing the right information at the right time." The interviewees described trust as being very much determined experientially, pointing out that trust is established if parties upheld their end of a deal and delivered what they promised in a timely manner. The interviewees also described trust as something that had to be "earned over time." Interviewees agreed that trust was highly important in agbiotech PPPs, such as the Bt maize project in South Africa. The findings of this study are amalgamated into four key lessons on trust building.

\section{The technology is nothing without the farmer: engage} the end user early to ensure adoption of the technologies

The importance of building trust between farmers and the private sector was articulated by some interviewees. One representative from the private sector stated: You have to build trust with your customers, which in our case would be the farmers. Establishing and maintaining the trust of farmers is essential for effective technology adoption. And as one small-scale farmer stated, "if I didn't trust them [Africabio], I wouldn't use their seed." Building trust with farmers has been shown to be achievable in a number of ways in South Africa. The following are some examples of practices that were used to build or erode trust between farmers and the private sector in the context of Bt maize in South Africa.

On-farm demonstrations One trust-building practice identified by farmers was the use of on-farm demonstrations that display the comparisons between Bt maize and conventional maize in the field. In 2001, Monsanto sought to engage with farmers by holding nine workshops across South Africa to introduce over 3000 small-scale farmers to Bt maize. Each farmer was given two bags of seed, one each of $\mathrm{Bt}$ and conventional maize, to plant in their own fields and compare the results [2]. This was one of the first farmer engagement initiatives undertaken by Monsanto after MON810, its GM event responsible for insect resistance in Bt maize, was approved for use in South Africa.

In a typical on-farm demonstration, seed companies or distributors would provide both Bt and conventional maize seeds for free to farmers to plant in a section of their fields and compare crop performance and yield. In addition, farmers were funded to host field days and invite other farmers in the community to observe the differences in performance at the demonstration sites. A farmer interviewee, commenting on this, said: Yes, we did not pay. They gave us [seeds] for free, and we planted the seeds. And then they helped us with money to hoe the fields and they come and they demonstrated the crops to other farmers. This practice was employed in six demonstration plots organized by AfricaBio between 2004 and 2005, which showed that there were higher yields of maize due to reduced stem borer infestations in Bt maize compared to the non-Bt maize [3].

Interviewees who had taken part in demonstrations described them as trust-building practices because of the support that seed companies and AfricaBio would provide to farmers in terms of supplying seeds, compensating for labor, and educating them about the technology. The primary goal of these on-farm demonstrations was to foster trust among attending farmers, who were able to judge first-hand the performance of Bt maize compared to traditional maize. Many interviewees corroborated the effectiveness of this practice. However, interviewees who had hosted on-farm demonstrations recounted the erosion of trust that occurred when promises of financial compensation for their efforts were withdrawn or left unfulfilled by the seed companies or distributors. Some farmers reported that they would no longer host field days and crop demonstrations due to this lack of compensation. A small-scale farmer interviewee said she "used to trust AfricaBio because of those things they were doing" but when support in cash and inputs dwindled, trust declined in a similar manner. 
Another farmer, making reference to the unreliability of the government arm to supply inputs, said, "we [farmers] don't look too much to the government."

Information dissemination and communication In addition to on-farm demonstrations, several interviewees felt that education and information dissemination about Bt maize was an important trust-building practice that could be achieved through a variety of avenues. One interviewee stated: the biggest trust creation is generating of science data, and then disseminating that data, and putting it out there on the website, in leaflets and all that so that the people understand what this is all about. One government initiative that contributed to trust building through education was the Public Understanding of Biotechnology Program. As indicated by the senior manager of the Technology Innovation Agency, this program sought to "demystify this passive talk about what biotechnology is and provide factual evidence [on what biotechnology is capable of doing]." Another initiative was the organization of regional study groups for farmers, the purpose of which was information and knowledge sharing among farmers.

One interviewee reflected on a positive trust-building experience he had with AfricaBio when they invited him to visit a university research laboratory to investigate the process of Bt maize development and discuss any concerns he had about the safety of the crop. The interviewee appreciated that AfricaBio "did not play hide and seek" about the technology but was willing to go to such an extent to educate him about Bt maize. A farmer, commenting on this issue, stressed the need for "straightforward channels" to foster good communication and stated, "If you have good communication, you can sort anything out."

2. The seed speaks for itself: delivering effective technology builds trust between the industry and the farmers

Many interviewees emphasized the importance of an effective technology - in this case, an effective Bt maize seedin building trust. An interviewee representing a seed company and distributer said that the ability of the technology to increase crop yields or reduce input costs is critical to the success of Bt maize: If it was a technology that was not providing benefits, they [farmers] would not be using it.

An interviewee from Monsanto attributed much of the project's success to "good genetics." A large-scale commercial farmer said: if you deliver a good product, you start to build trust in that product. One small-scale farmer also stated, "We're building trust with the seed itself [...]. The performance of the seed is what you trust." In the case of the Bt maize project in South Africa, "the trust held in place because the technology worked," said an independent researcher.

Guarantee that the Bt maize technology works and honesty about its expected performance was cited as an important trust-building practice by the private sector. An interviewee from Monsanto described it thus: They [farmers] need to trust you that the product they're buying from you will perform to expectation. In order to ensure that realistic expectations are set, an interviewee from another private seed company said, "we never misrepresent whatever information that we share. So if a product does not perform, we will say that it does not perform. If a product does not perform, we will not take it to the market."

Despite these intentions, some interviewees described instances when the performance of the Bt maize technology did not meet their expectations. A few of these instances created an opportunity to build trust as some private companies took responsibility for the product failures and compensated the farmers affected. From one farmer's perspective, this "built a lot of trust. Because that's putting your money where your mouth is." The important lesson on trust that resulted from these cases can be summarized by the following statement made by an industry representative: The farmer knows that if there is a problem that he could come back to the company to say 'listen, there is a problem' and the company then attends to the problem to resolve it.

In other cases, instances of product failure resulted in the erosion of trust between the farmer and private seed company when the latter failed to acknowledge or take responsibility for the reported discrepancies. As one farmer stated, "I don't have any trust in your [the seed company's] product anymore. Because the technology is failing under certain circumstances and [the seed company] don't acknowledge that."

The benefits of these trust-building practices can be significant. In particular, once trust is established between the farmers and the private companies, or between the farmers and the seed companies, the power of word-ofmouth within the farming community can be a great asset to the private sector. As one small-scale farmer described, "What I've done is to tell other farmers that I'm planting this [Bt maize seed], [and that] this is going to help you to get more yield."

Acknowledging faults and taking responsibility in instances of product failure was found to be an important trust-building practice. The failure to do so, however, was cited by some interviewees as a great barrier to trust building and in some instances led to ceasing use of the technology. Ensuring that Bt maize performs as expected and is beneficial to the farmers is therefore important for the adoption of the technology and the maintenance of trust between farmers and the private sector.

\section{Full disclosure facilitates regulatory processes and enhances mutual trust between industry and government}

The regulatory process for GM crops in South Africa is outlined in the GMO Act, which was passed in 1997 
and came into effect in 1999 [15]. This Act created the Executive Council, which is a decision-making body that is responsible for approving or rejecting applications to commercialize GM crops [15,16]. Monsanto's MON810 was approved for commercial production by the Department of Agriculture in 1998, upon the recommendation of SAGENE. Syngenta's Bt maize was likewise approved in 2003 [4]. In order to build trust during the regulatory approval process, it is important that both the applicant and the regulator fully disclose all relevant information throughout the process.

On the government side, it is important to clarify the requirements for regulatory approval and communicate them to the private companies. As stated by a former regulator and now a seed company executive, the early stages of developing the Bt maize was a learning process for the regulators that was enhanced by open communication with the industry. Because Bt maize was the first GM crop product, the regulators "were not really sure what exactly they wanted to see or to evaluate to determine safety." Open communication between regulatory bodies and private companies was therefore a "big factor that added to building trust," which in turn led to better compliance to the regulatory process.

Once the requirements for regulatory approval are clearly communicated, it is important that the private sector fully discloses all information necessary so that the regulators can make decisions about the technology. The government needs to be able to trust that the private sector will "give accurate information, truthful information, not withhold the information that could impact their decision. And to comply with any conditions that have been given." In return, the private sector must feel assured that the government will maintain confidentiality on all sensitive product information.

The mutual trust built between the regulator and industry has led to enhanced communication and consultation between them. For example, an interviewee from the seed industry noted that, when lobbyists or anti-GMO organizations lodge a complaint against Bt maize technology, the government trusts the private sector enough to approach them by "say[ing] that 'this is an accusation that came in pertaining to your products, what information can you give us?"' This positive relationship was enabled by mutual trust between the regulatory bodies and private sector stakeholders.

\section{Good agronomic practices sow success and foster trust}

Another important issue related to trust was the upholding of good agronomic practices by the farmers when growing Bt maize. Good agronomic practices include the distancing of GM and non-GM crops physically and temporally, and planting refuge areas in order to prevent insect resistance build-up to transgenic crops such as Bt maize [17]. Refuge areas, or refugia, are the buffer zones of
non-Bt maize (susceptible to stalk borers) planted in close proximity to $\mathrm{Bt}$ maize to provide a pool of stalk borers susceptible to Bt maize. This is meant to delay development of resistance to the toxic protein produced by $\mathrm{Bt}$ [18]. As South Africa was the first African country to report stem borer resistance to the Bt toxin, the need to ensure a proper refuge area is becoming more important. Many interviewees (including farmers, industry and government executives) emphasized the importance of planting Bt maize correctly and particularly underlined the importance of enforcing the planting of the refuge area between conventional and Bt maize.

Farmer interviewees attributed positive trust-building experiences to good agronomic practices: number one, we planted exactly the way they [the seed company] said. They taught us how to plant and we did exactly what they said. And then they told us that we must de-weed every time we see the weeds coming out. And we did exactly what they said... that's why our maize was so beautiful. Enforcing these agronomic practices is not only beneficial to the farmer but also to the companies selling the technology. As an interviewee from a seed company described: We want to make sure that they [farmers] also plant the refugia, and that they abide by the rules. It's of interest to all of us. Refugia is not something to make it difficult; it's there to protect the traits. We want it to be protected for as long as possible.

Failure to enforce the refuge area, on the part of both farmers and the private sector, was cited as a challenge to building trust. Some farmers chose not to plant a refuge area due to their desire to maximize profits per unit area. They said they were hesitant to reserve a portion of their fields for a refuge area of conventional maize, which would produce lower yields compared to Bt maize and, in turn, lead to reduced profit. Moreover, other farmer interviewees recalled that some seed companies fail to enforce the refuge area by neither educating their customers about the need to plant nor monitor it. One farmer stated, "they [seed companies] don't promote the refugia areas enough," and each time the seed company sold seeds to him, he would ask, "'but what about my maize for my refugia area?" He further stated: They don't tell you that if you're going to buy 100 bags, 95 bags must be Bt and 5 bags must be for your refugia area. What ensues from industry member's failure to ensure appropriate management of the refuge area is the erosion of trust between the farmer and the private sector. While the private sector companies are hesitant to trust farmers to use proper agronomic practices, some farmers cannot trust seed distributors to adequately promote and provide the necessary conventional maize to plant their refuge area. In order to maintain trust and protect the effectiveness of the Bt maize technology, it is critical that both farmers and the private 
sector work together to enforce and monitor proper agronomic practices.

\section{Conclusions}

The success of the Bt maize project in South Africa has been, and will continue to be, dependent upon the concerted effort of the farmers; government; and private sector stakeholders to establish and maintain trust. The four key lessons on trust building that were drawn from this case study can be applied to other agbiotech PPPs attempting to successfully introduce GM technology in sub-Saharan Africa. Each of the trust-building practices described in this case study require collaboration among stakeholders, though most can be undertaken without substantial financial inputs from any one partner. In interactions between the government and the private sector, transparency; accountability; and open communication are critical for navigating the regulatory process. When establishing trust with farmers, it is essential that the private sector be open and candid about both the benefits and limitations of their technology. This should include information sharing and awareness-building practices, such as the on-farm demonstrations described in this study. To maintain this mutual trust, farmers should also endeavor to employ the technology responsibly and uphold proper management practices, such as planting a refuge area. Each of the practices and principles presented in this case study has been shown to be essential for trust building in the context of the Bt maize project in South Africa. If applied with concerted effort, the key lessons presented in this study can provide a roadmap for budding agbiotech PPPs in designing their strategy for building trust with farmers and ensuring the successful adoption of their technology.

\section{Additional material}

Additional file 1: Key collaborators/partners in the Bt maize partnership in South Africa.

Additional file 2: Sample interview questions.

\footnotetext{
Acknowledgements

The authors are grateful to each of the participants who contributed substantial time and effort to this study. Special thanks to Justin Mabeya for assisting with data collection. The authors also thank Jessica Oh and Jocalyn Clark for comments on earlier drafts of the manuscript.

This project was funded by the Bill \& Melinda Gates Foundation and supported by the Sandra Rotman Centre, an academic centre at the University Health Network and University of Toronto. The findings and conclusions contained within are those of the authors and do not necessarily reflect official positions or policies of the foundation. This article has been published as part of Agriculture \& Food Security Volume 1 Supplement 1, 2012: Fostering innovation through building trust: lessons from agricultural biotechnology partnerships in Africa. The full contents of the supplement are available online at http://www.agricultureandfoodsecurity.
}

com/supplements/1/S1. Publication of this supplement was funded by the Sandra Rotman Centre at the University Health Network and the University of Toronto. The supplement was devised by the Sandra Rotman Centre.

\section{Author details}

${ }^{1}$ Sandra Rotman Centre, University Health Network and University of Toronto, Toronto, Ontario, Canada. ${ }^{2}$ African Centre for Innovation and Leadership Development, Federal Capital Territory, Abuja, Nigeria. ${ }^{3}$ Dalla Lana School of Public Health, University of Toronto, Toronto, Canada. ${ }^{4}$ Grand Challenges Canada. ${ }^{5}$ Dalla Lana School of Public Health and Department of Surgery, University of Toronto, Toronto, Canada.

\section{Authors' contributions}

Study conception and design: OCE and ASD. Data collection: OCE. Analysis and interpretation of data: OCE and RL. Draft of the manuscript: OCE, RL and ASD. Critical revision of the manuscript for important intellectual content: OCE, RL and ASD. All authors read and approved the final manuscript.

\section{Competing interests}

The authors declare that they have no competing interests.

Published: 1 November 2012

\section{References}

1. Gouse M, Pray C, Schimmelpfennig D, Kirsten J: Three Seasons of Subsistence Insect-Resistant Maize in South Africa: Have Smallholders Benefitted. AgBioForum 2006, 9(1):15-22.

2. Gouse M, Kirsten JF, van der Walt WJ: Bt Cotton and Bt maize: An Evaluation of Direct and Indirect Impact on the Cotton and Maize Farming Sectors in South Africa. 2008.

3. Keetch DP, Webster JW, Ngqaka A, Akanbi R, Mahlanga P: Bt maize for small scale farmers: a case study. Afr J Biotech 2005, 4(13):1505-1509.

4. Gouse M, Pray C, Kirsten J, Schimmelpfennig D: A GM subsistence crop in Africa: the case of Bt white maize in South Africa. Int J Biotechnology 2005, 7(1-3):84-94.

5. James C: Global status of commercialized biotech/GM crops:2011. ISAAA Brief No 432011.

6. South African National Seed Organisation [http://www.sansor.org/ features/biotechinsa1101.htm].

7. Gouse M: South Africa: Revealing the Potential and Obstacles, the Private Sector Model and Reaching the Traditional Sector. In The Gene Revolution: GM Crops and Unequal Development. London, UK: Earthscan; Fakuda-Parr S 2007:176-195.

8. AfricaBio [http://www.africabio.com//pages/about-us.php].

9. Zheng J, Roehrich J, Lewis MA: The dynamics of contractual and relational governance: Evidence from long-term public-private procurement arrangements. Journal of Purchasing and Supply Management 2008, 14:43-54

10. Spielman DJ, Hartwich F, von Grebmer K: Public-Private Partnerships in International Agricultural Research. International Food Policy Research Institute 2007, 9:1-6.

11. Spielman DJ, Grebmer K: Public-Private Partnerships in International Agricultural Research: An Analysis of Constraints. Journal of Technology Transfer 2006, 31:391-300.

12. Ezezika OC, Daar AS, Barber K, Mabeya J, Thomas F, Deadman J, Wang D, Singer PA: Factors influencing agbiotech adoption and development in sub-Saharan Africa. Nature Biotechnology 2012, 30:38-40.

13. Brewer B, Hayllar MR: Building public trust through public-private partnerships. International Review of Administrative Sciences 2005, 71(3):475-492.

14. White-Cooper S, Dawkins NU, Kamin SL, Anderson LA: Communityinstitutional partnerships: understanding trust among partners. Health Educ Behav 2009, 36(2):334-347.

15. Wolson R: Assessing the Prospects for the Adoption of Biofortified Crops in South Africa. AgBioforum 2007, 10(3):184-191.

16. South African Government Information [http://www.info.gov.za/acts/ 1997/act15.htm].

17. Viljoen C, Chetty L: A case study of GM maize gene flow in South Africa. Environmental Sciences Europe 2011, 23(8):1-8. 
18. Vacher $C$, Bourguet $D$, Desquilbet $M$, Lemarié $S$, Ambec $S$, Hochberg ME: Fees or refuges: which is better for the sustainable management of insect resistance to transgenic Bt corn? Biol Lett 2006, 2(2):198-202.

doi:10.1186/2048-7010-1-S1-S3

Cite this article as: Ezezika et al:: Strategies for building trust with

farmers: the case of Bt maize in South Africa. Agriculture \& Food Security 2012 1(Suppl 1):S3.

Submit your next manuscript to BioMed Central and take full advantage of:

- Convenient online submission

- Thorough peer review

- No space constraints or color figure charges

- Immediate publication on acceptance

- Inclusion in PubMed, CAS, Scopus and Google Scholar

- Research which is freely available for redistribution

Submit your manuscript at www.biomedcentral.com/submit 